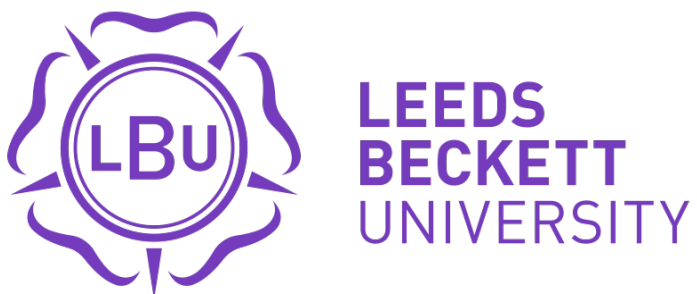

Citation:

Singh, D (2016) Anti-corruption Strategies in Afghanistan: An Alternative Approach. Journal of Developing Societies, 32 (1). 44 - 72. ISSN 0169-796X DOI: https://doi.org/10.1177/0169796X15609714

Link to Leeds Beckett Repository record:

https://eprints.leedsbeckett.ac.uk/id/eprint/2645/

Document Version:

Article (Accepted Version)

The aim of the Leeds Beckett Repository is to provide open access to our research, as required by funder policies and permitted by publishers and copyright law.

The Leeds Beckett repository holds a wide range of publications, each of which has been checked for copyright and the relevant embargo period has been applied by the Research Services team.

We operate on a standard take-down policy. If you are the author or publisher of an output and you would like it removed from the repository, please contact us and we will investigate on a case-by-case basis.

Each thesis in the repository has been cleared where necessary by the author for third party copyright. If you would like a thesis to be removed from the repository or believe there is an issue with copyright, please contact us on openaccess@leedsbeckett.ac.uk and we will investigate on a case-by-case basis. 


\title{
Anti-corruption Strategies in Afghanistan: An Alternative Approach
}

\author{
Danny Singh \\ University of York, North Yorkshire
}

\begin{abstract}
Afghanistan is one of the most corrupt countries in the world. This article provides a critical examination of Afghan anticorruption strategies based on formal anticorruption strategy, bureaucratic reform, and counter-narcotics. This article includes reference to some of the opinions of 70 semi-structured interviews conducted by the author in Kabul during May-June 2010 with anticorruption experts, rights-based organizations, civil society groups, ministries, and international and national organizations. The findings are that political interference from Afghan elites preserves corruption and deep roots of patron-client corruption-patronage networks and illicit drug trafficking interests with criminal groups for profitable gain-are difficult to combat with the existing anticorruption strategy. Hence, new approaches need to be attempted, such as, incorporating religion and ethics and empowering local leaders to combat corruption within a sixfold approach which involves (i) raising awareness, (ii) prevention, (iii) prosecution and sanctions, (iv) detection, (v) a collaborative counter-narcotics strategy, and (vi) linking religion.
\end{abstract}

Keywords: anticorruption, bribery, state capture, patronage, clientelism, drug trafficking, religion, Afghanistan

\section{Introduction}

In Afghanistan, the main causes and practices of corruption range from administrative corruption, clientelism and patronage, low pay and bribery, drug-related corruption to state capture. Corruption in Afghanistan entails daily bribery for basic public services and aid cor-ruption that affects the poor severely. Civil servants, public sector employees, and law enforcement actors - the police and judges-regularly demand bribes to speedup transactions as survival-based corruption to supplement low pay. ${ }^{1}$ In addition, parts of the state have been captured 
by non-state criminal networks and armed opposition groups (AOG) in which elites, government officials, and police chiefs serve and protect criminals and former President Hamid Karzai's cronies' illicit lucrative drug trafficking. The government interferes in police, judicial, and anticorruption investigations, resulting in either the release of drug mules or avoidance of investigation. $^{2}$ Patron-client relations concerning appointments and positions are purchased and sold in lucrative poppy-rich areas in exchange for loyalty, and a lump sum or monthly stipend of bribes collected is paid to the recruiter or superior. ${ }^{3}$ In Afghanistan, the root cause of corruption is debatable, but it is difficult to challenge corruption and clientelism in a state that is run by patronage appointments based on kinship and similar interests. ${ }^{4}$ All of these factors pose challenges to the rule of law, security, anticorruption, and more broadly statebuilding.

This article critically examines anticorruption strategies that attempt to combat the aforementioned issues of corruption and clientelism based upon 70 semi-structured interviews conducted by the author in Kabul. Bureaucratic reform efforts to curb corruption are critically evaluated. This includes the Afghanistan National Development Strategy (ANDS); the Afghanistan Compact and London, Paris, and Kabul Conferences; Public Administration Reform (PAR) and Civil Service Reform; and the development and adoption of the High Office of Oversight and Anticorruption (HOOAC). The formal anticorruption reform attempted does comply with the challenges recognized by powerful international donors. This includes reforming state institutions and increasing the salaries of public officials and civil servants; good governance, the rule of law, and human rights; counter-narcotics and alternative livelihoods; and enhancing the capacity of civil society organizations (CSOs) to raise awareness and combat administrative corruption. Yet, it is the state cap-ture and persistent patron-client relations-partially derived from the Bonn Agreement that empowered warlords into political positions - that have resulted in the failure of the formal anticorruption strategy.

The subsequent part includes the argument that religion and ethics could be applied with anticorruption strategy to change these underlying systems. Trusted local power-holders can be trained and empowered to curb corruption in the countryside and build accountability from bottom-up. The article ends with recommendations based on a sixfold approach of combating corruption more effectively in Afghanistan by: (i) raising awareness, (ii) prevention, (iii) prosecution and sanctions, (iv) detection, (v) a collaborative counter-narcotics strategy, and (vi) linking religion. 
The new Afghan President, Dr Ashraf Ghani Ahmadzai, has a huge challenge of curbing corruption in order to restore faith and legitimacy in the state.

\section{Afghanistan National Anticorruption Strategy}

Corruption has been acknowledged as a major obstacle to Afghan development, which was reiterated in the 2006 Afghanistan Compact ${ }^{5}$ and the ANDS. The role of civil society institutions and nongovernmental organizations (NGOs) needs to be strengthened to reduce poverty and improve security, eradicate the drug industry, strengthen governance, and decrease corruption to enhance stable macroeconomic policies and development (ANDS, 2008, pp. 36, 39, 54). Similarly, the ninth aim of the Afghanistan Compact (2006, p. 3) is to "combat corruption and ensure public transparency and accountability." Moreover, the Afghanistan Compact (2006, p. 7) set targets to ratify the United Nations (UN) Convention against Corruption (UNCAC) with national legislation and establish an oversight mechanism to oversee anticorruption strategy implementation. The main aim of the ANDS is to plan and implement a strategy to benefit the poor in compliance with a Poverty Reduction Strategy Paper that is budgeted, sequenced, and prioritized to combat corruption. Corruption is a main indicator of poverty. The poor pay a higher slice of their incomes as bribes on a daily basis to attain services that should be free (Singh, 2014, p. 626).

Point 9 of the Principles of Cooperation at the London Conference strives to curb corruption and guarantee public transparency and account-ability (Afghanistan Compact, 2006, p. 2). In addition, the 2020 Vision for Afghanistan strives for more accountable institutions for responding to the poor that are also involved in decision-making processes, irrespective of gender or social status. The Vision hopes for a firm Islamic constitu-tional democracy with peaceful relations with its neighbors, a pluralistic nation honoring Islamic heritage and participation, justice and equal rights, and a developed private sector.

The three predominant pillars of the ANDS are (i) security; (ii) governance, rule of law, and human rights; and (iii) economic and social development. Security is recognized as a fundamental prerequisite for development in the country and the Afghanistan Compact (2006, p. 3) supports the International Security Assistance Force, Provincial Reconstruction Teams, Operation Enduring Freedom, the close coordination of donors involved in 
Security Sector Reform (SSR), and backing of the Afghan government to establish security and stability. The Paris Conference (2008) aims to implement the ANDS to achieve the objectives of the Afghanistan Compact to serve Afghan security, economic development, and human rights in every village and combat corruption and support counter-narcotics efforts.

The second pillar, governance, rule of law, and human rights, under-lines that the Afghan government should enhance accountability and transparency within the government. This includes adopting meritocratic appointments in the public sector, including the civil service, police, and judiciary, and fighting corruption, upholding the rule of law and human rights (Afghanistan Compact, 2006, p. 3). In relation to the protection of human rights, the National Action Plan for the Women in Afghanistan (NAPWA) has aimed to protect women's equal legal rights, promote better access to justice and human rights, security, and opportunities (ANDS, 2008, pp. 14, 36; Paris Conference, 2008, p. 3). The NAPWA is a 10-year action plan for mainstreaming gender equality in Afghan govern-ment institutions, compliant with the Afghan Constitution and the 1979 Convention on the Elimination of All Forms of Discrimination against Women. Moreover, PAR is included in the 2020 Vision to encourage the progress and performance of institutions with competent merito-cratic appointment-based recruitment, including the provincial level to fight nepotism and corruption and protect CSOs. The ANDS recognizes that Afghanistan's public institutions are in their infancy, corruption is endemic, legal enforcement to implement the laws is dire, parliamentary oversight is weak, gender inequality is prevalent, and the judiciary and human rights enforcement are underdeveloped.

The third pillar recognizes that a liberal market, private sector growth, and counter-narcotics are crucial for developing the country's economy and eliminating the threat that the drug industry poses to the Afghan government and international security (ANDS, 2006, p. 16; Paris Conference, 2008, p. $2)$. The Afghan government is instructed to significantly reduce the cultivation and smuggling of drugs with the cooperation of the neighboring countries. In addition, the Afghan government has been urged to support international interdiction efforts, provide alternative livelihoods for farmers, enforce zero tolerance to official corruption, and improve law enforcement (Afghanistan Compact, 2006, p. 4). The ANDS, similar to the Afghanistan Compact, recognizes that corruption in the public sector, excessive centralization, and narcotics-affiliated infiltration are huge obstructions to security and development 
(ANDS, 2008, pp. 21, 55, 63). The ANDS has six cross-cutting issues that include counter-narcotics and anticorruption.

The National Drug Control Strategy (NDCS), initially prepared in 2003 and updated on several occasions, has been addressed to the Afghan government to establish effective disruption of the narcotics trade by targeting smugglers and supporters. The Ministry of Counter Narcotics is mandated to implement the NDCS to strengthen alternative licit rural livelihoods. This is to reduce the demand for drugs, rehabilitate drug users, and enhance both central and provincial institutions that play a key role in counter-narcotics and drug interdiction (Kabul International Conference on Afghanistan, 2010, pp. 9, 42, 44). In addition, reinforcing the integrity of counter-narcotics and publicizing accessible information on donor aid at both the central and provincial levels are part of the counter-narcotics strategy (ANDS, 2008, pp. 149, 159).

Despite corruption, the international community has attempted to curb corruption by prescribing anticorruption strategies such as the anticorruption road map. Afghanistan's anticorruption road map is based on enhancing its leadership, raising awareness, mainstreaming anticorruption across the government, enhancing legal enforcement for combating corruption, and building the capacity to implement UNCAC (ANDS, 2008, pp. 14, 73). The road map was produced by the UN, the World Bank, the Asian Development Bank (ADB), and the United Kingdom (UK) for the Afghan government to effectively target its resources to combat corrupt networks. The specified target was to significantly reduce corruption at all levels of the government, particularly the security and customs sectors, by the end of 2013 and implement a monitoring mechanism to trace corruption at high levels of the government and security organizations by the end of 2008. Increased monitoring at senior levels and complaint mechanisms and public reporting are part of the strategy (ANDS, 2008, p. 64). However, after almost two years of nationwide consultations, the ANDS suffered from donors' lack of support and poorly organized prioritization that failed to report on their objectives (Jackson, 2010, p. 3).

Moreover, unrealistic time frames have been set in relation to SSR. The ANDS states that the Afghan National Police (ANP) will be a com-petent, constituted, functional, and professional force by the end of 2010 and meet the security needs of the people, and both the Afghan National Army (ANA) and ANP will be able to perform missions against external and internal threats effectively (ANDS, 2008, p. 56). However, the ANP is 
the most hated institution in the country and is renowned for corruption and incompetence and the ANA is absolutely incompetent to perform independent operations. ${ }^{6}$ Furthermore, the ANDS $(2008$, p. 194) states that the Ministry of Counter Narcotics and the Ministry of Interior (MoI) are responsible for training and strengthening the capacity of the Afghan police to enforce law against narcotics smuggling and poppy production by 2013 . Yet, MoI officials and the ANP are involved in the drug trade. Up to 80 percent of the Afghan police is profiting from "the drug trade in some regions" (Giustozzi \& Isaqzadeh, 2013, p. 89).

Despite the unrealistic time frames set by both London and Paris conferences, the ANDS has been particularly useful in establishing the main problems that Afghanistan faces. The ANDS (2008, pp. 3-4) acknowledges that poverty is widespread, security is dire, the government has weak capacity and is corrupt, the country has poor private sector investment and a growing drug industry, and these problems will take many years with continual international support to rectify. Prevalent corruption in the public sector and the security services has discouraged private investors to capitalize in risky businesses. In addition, the growing drug industry, as a result of insecurity, has fuelled public sector corruption and increased poppy cultivation due to the lack of alternative livelihoods. Illegal AOGs throughout Afghanistan have close ties with the Afghan police and some belong to the local governments heightening corruption, which plays a fundamental obstacle in fighting the drug industry (ANDS, 2008, pp. 5-6, $55)$.

\section{Public Administration Reform and Civil Service Reform}

In Afghanistan, PAR has been installed to build a competent civil service that is managed by formal rules in structured and organized central and subnational levels. The legal basis of PAR was provided by the Bonn Agreement that established the Independent Civil Service Commission, which was later extended to the Independent Administrative Reform and Civil Service Commission (IARCSC) ${ }^{7}$ to reform the ministries. The IARCSC holds the responsibility of appeals, appointments, management, and administrative reform. Merit-based appointments are monitored by the IARCSC that includes a recruitment and appeals board. The central representative for PAR is the Administrative Reform Secretariat that ensures the monitoring over the recruitment of merit-based appointments under the 2005 Civil Service Law. The IARCSC has three working stages, 
namely, Priority Reform and Restructuring (PRR), PAR, and Pay and Grading $(\mathrm{P} \& \mathrm{G})$ with the responsibility of administrative and managerial reform, appointments, and appeals.

First, PRR was introduced on July 10, 2003, by a decree that restruc-tured 90 percent of the civil service and has trickled down to all of the ministries to raise the fixed-pay scale of important staff. Priority Reform and Restructuring includes the planning and implementation of a P\&G scheme that is complemented with a retraining, redeployment, and reskilling program to manage excess civil servants and downsize excess governmental staff. ${ }^{8}$ Priority Reform and Restructuring involves taking examinations to ensure that the employees are up to scratch and then they are reemployed with higher salaries because "unless you pay the people proper salary, you're going to invite them to be corrupt." ${ }^{\text {"9 }}$ However, according to the IARCSC (2005), PRR has focused more on pay improve-ments rather than the restructuring of ministerial departments' processes, and therefore enforcing competitive-based meritocratic appointments has failed at the implementation level.

Second, PAR was installed to enhance the capability of the govern-ment to provide security, basic social services, prepare job descriptions, and recruitment. The ADB (2005) initially approved the funds of United States Dollar (US\$) \$105 million for the PAR program to the Afghan government that included numerous periodic grants for capacity-building. This was to create an administration to reduce poverty, enhance develop-ment and economic growth, and improve public services by downsizing ministries and reinstating their functions. This strategy was endorsed to eradicate overlaps in the same jobs within ministries to achieve better productivity, reduce costs, and improve the full use of limited skills. Senior civil servants supported their cabinet ministers and deputy ministers and operated as a secretary general of each ministry.

Third, $P \& G$ strengthens the competence of public employees by improving pay and with a systematic grading system in accordance with rank, experience, and skills, with prospects for career progression to establish a professional and meritocratic civil service. The recruitment of civil servants at Grade 2 and higher is identified by the Independent Appointments Board, and the Board reviews the recruitment and promo-tion processes for civil servants below this scale, which is carried out by governmental ministries. General civil servants at the lowest skill level, Grade 10, were paid Afghanistan Afghani (AFN ${ }^{10} 1,818$ per month, which was increased to AFN 2,058 monthly; Grade 5 increased from AFN 1,848 
to 2,268 monthly and Grade 1 earned AFN 1,908 per month prior to the pay rise which was increased to AFN 2,688 monthly after the late 2003 pay rise. This has trickled down to the defense ministry. The ANA pay reform has streamlined the senior ranks and increased the numbers of the lower ranks to raise the salaries of all ranks, with the lowest ranked Grade E-4 soldier earning USD 100-180 per month, second lieutenant Grade O-1 receiving \$190-270 monthly, and the highest ranked Grade O-10 generals earning \$880-1,030 per month (Leonard, 2008, p. 20).

Although there have been many problems with the open and fair recruitment process, the Independent Appointments Board has appointed 1,500 senior civil servant positions utilizing a merit-based appointment policy. The World Bank works on civil service reform "to make the civil service a more technocratic body subject to the usual restraints and controls" and $P \& G$ is "trying to actually increase people's salaries" because "these administrators are not earning enough money" and the "prosecutors and judges need to be paid higher salaries that actually incentivize them to do their job."11 However, a United Nations Office on Drugs and Crime (UNODC) survey of December 2012 in Afghanistan reveals that only 7 percent of household members applying for the civil service claimed that they were unsuccessful due to merit, whereas 51 percent believed that cronyism and nepotism were the main practices. Thirty-nine percent said that bribes paid played a pivotal role in the public recruitment process (UNODC, 2012, p. 19).

Despite the implementation of the IARCSC and international donor support from the US Agency for International Development (USAID), the World Bank, and ADB, PAR has been criticized by donors for operating at a slow rate. Donors involved have reported that pay reform has been difficult to implement in practice (Lister, 2007, p. 6). According to the ANDS (2006, p. 16), the Afghan government's main goal is to provide an "effective, accountable, and transparent public administration at all levels of government" that include the subnational level.

However, PAR at the provincial level is difficult due to its distance from the capital, which does little to reform the diversity and complexity of local patronage appointments. Public Administration Reform attempts to reform bureaucracies and control resources to combat patronage systems, but this is resisted at the provincial level and PAR is also weakly implemented at centralized ministerial levels (Suhrke, 2007). Presidential authorities have consequently liaised with less senior levels to form a stronger reliance on secretive economic networks. The central 
government is involved in secretive dealings within the illicit opium economy, which involve local governors, power brokers, and warlords in the countryside. Moreover, the local government is complex as there are 34 provinces, with an estimated 364 districts, and each province contains a municipality, often with one rural municipality. The local government in provinces and districts functions in compliance with centralized policy decisions; although flexibility is allowed and some regions are not mentioned in the Afghan Constitution, they are utilized for administrative convenience.

\section{Development and Practice of the HOOAC}

In July 2008, the HOOAC was established by the Presidential Decree to work with departments and ministries to reduce bureaucratic opportunities for engagement in corruption, enhance public information via education, and raise awareness from outreach programs to the civil society. The HOOAC was enacted under Section 3 of Article 75 of the 2004 Afghan Constitution to eliminate administrative corruption with Article 142 of the Constitution to create necessary offices and Article 6 of UNCAC to oversee the strategic implementation of anticorruption practices. The Afghan government ratified UNCAC on August 25, 2008. The preamble of UNCAC recognizes that corruption weakens the security and stability of the country and undermines institutions, democracy, sustainable development, justice, and the rule of law.

The HOOAC is regarded as the highest office for coordination and implementation of Afghanistan's national anticorruption strategy, which includes UNCAC to investigate government corruption and retain independence from political interference. The sincere aims of the HOOAC are to fight corruption through coordination, prevention, and raising awareness, which are the methods used in approaches to curb corruption. The HOOAC immediately launched a nationwide "TV and radio anticorruption campaign" including asset declaration for senior government officials, established a collaborative website for Afghans to complain about corruption and officials, and created a corruption complaints office to deal with hundreds of verbal and written complaints every week (The Asia Foundation, 2009). In addition, the National Directorate of Security (NDS) is mandated to counter drug offences, organized crime, and corruption, where it refers information to the Attorney General's Office (AGO), HOOAC, and the police, and 
allegations against high-profile officials are submitted to the president who decides the further course of action.

The HOOAC has no prosecution powers; therefore, monitoring is the High Office's main anticorruption strategy that oversees the enactment of government offices regarding the implementation. However, only 15 cases have been transferred to law enforcement agencies, which have resulted in only a handful of arrests (Arnoldy, 2010). Furthermore, planning has been done by the majority of ministries, such as, the 17 articles of the MoI, but implementation has not yet been stamped into the ministries. Cooperation, coordination, and capacity at the governmental level concerning Afghanistan's anticorruption strategy are inadequate and the HOOAC is absent at the provincial level, similar to the Afghan central government. Hence, corruption has been formally addressed, but no real action has been undertaken to move beyond political rhetoric and unfilled pledges (Jackson, 2010, p. 2).

Despite the creation of the HOOAC to boost awareness and investigate corruption cases, it is not truly independent from the Afghan government, which can override or ignore challenges on government officials, and does not exercise independence in corruption cases. Therefore, the High Office remains attached to the Presidential Office and is unable to reduce political interference, particularly in high-profile cases, and corruption is prevalent in all sectors across Afghanistan. ${ }^{12}$ Political interference is the outcome when a high-level official is probed with drug or corruption allegations, which retains their immunity from prosecution and abolishes law enforcement and application of existing antidrug and anticorruption laws. ${ }^{13}$ It has been contended by the Country Director of Global Rights that the HOOAC is unconstitutional and futile in performing independent investigations of corruption. ${ }^{14}$ It is also argued that it will take a genera-tion or more for Afghan state justice to be less corrupt and function at basic standards. ${ }^{15}$

Similarly, the Control and Audit Office (CAO) is attached to the Office of the President and lacks independence and capacity due to weak laws and political interference to perform its financial auditing of government agencies. ${ }^{16}$ Moreover, the HOOAC has an ineffective relationship with the AGO, runs under the control of the president, is politically manipulated, is understaffed, has inadequate powers to pursue investigations, and most employees lack experience or competence to deal with complex corruption investigations (Special Inspector General for Afghanistan Reconstruction [SIGAR], 2009, p. 6). For instance, the 
High Office has slowly started publishing the asset declarations of senior government officials, but some have refused to complete these despite the request of the Office and former President Karzai. The HOOAC is unwilling to commence reforms. Further investigations are avoided when they are deemed politically sensitive. It is contended that the HOOAC Chief, Mohammad Yasin Osmani (at the time of interview), applies flexibility and "leaves cases on the shelf" to avoid holding certain figures with political connections accountable. ${ }^{17}$ Moreover, Karzai appointed Azizullah Lodin, the ex-head of the International Election Committee who was previously dismissed in 2009 over election fraud, as the new HOOAC Chief.

In Afghanistan, the roots of corruption have spread to the top level and eradicating these corrupt officials will remove the main root of corruption, but a mafia-style system of untouchables makes this difficult. ${ }^{18}$ It is argued that more robust commitment is required from the top to implement the laws "whether they are weak or revised"; however, "the unfortunate thing in this country is that we never hit them with any laws." 19 Powerful drug lords associated with the Karzai government have the "freedom to travel and network" (Hafvenstein, 2011, p. 125), and are virtually immune from prosecution due to unstable security conditions (Saghafi-Ameri, 2010, p. 227). For example, former President Karzai pardoned five convicted narcotics traffickers caught with over $260 \mathrm{lbs}$ of heroin who were sentenced to 16 and 18 years imprisonment, including Karzai's 2009 election campaign manager, Bilal Wali Mohammad (Farmer, 2009). This indicates that all judicial bodies are manipulated and ineffective due to influential patronage networks, a lack of national political will to enforce existing laws, and endemic corruption, which allows empowered persons or groups to evade their legal accountabilities.

Civil society is either skeptical or unaware of the HOOAC and IARCSC's fight against corruption. In relation to raising awareness and the competence of agencies fighting corruption, such as the HOOAC and IARCSC, only 44 percent and 48 percent of Integrity Watch Afghanistan (IWA) survey respondents had heard of these, respec-tively (IWA, 2010, p. 31). In addition, 63 percent stressed that there had not been any improvements and 26 percent did not know whether they believed that there had been some improvements in the reduction of corruption in any public institution over the past year (IWA, 2010, p. 31). This demonstrates that the civil society is not thoroughly included in combating corruption, and lacks the knowledge of certain anticorruption 
bodies and "strengthening civil societies"; raising awareness and changing behavior via media and education are needed for future anticorruption reform (Azami, 2009).

Poor leadership in the Afghan Supreme Court and the government has failed to stamp out corruption and proceed and support the HOOAC's investigations. ${ }^{20}$ It is difficult to enhance leadership with the current "Head of State in Afghanistan" but if there is someone really dynamic in the Supreme Court and other robust reformers who "throw people in jail for violations then it's possible to combat corruption." ${ }^{21}$ Currently, political will does not exist in Afghanistan due to the lack of independence of key institutions such as the HOOAC and Major Crimes Task Force (MCTF). These institutions are undermined by political interference; for example, former President Karzai protecting his political cronies, which hinders investigations of corruption at the senior level.

It helps if an important person like a governor can help stamp out corruption by being serious but corruption is a part of business in provinces and throughout the system. So it is possible but we don't have people like that in the court or in the government. It's going to be a challenge. ${ }^{22}$

Similarly, the leadership and political will of the senior officials within the government and its ministries need to be stronger to stamp out corruption, but this is a generational shift where formal education is needed which could take 20-30 years for the government to show strong leadership and political will. ${ }^{23}$ Stronger political will is needed in a few leaders who are serious about actually fighting corruption because currently the Afghan state and all its efforts are failing with leaders changing the laws and decrees to suit their interests. $^{24}$ This is clear evidence of state capture. Manipulation by the Afghan leaders preserves their immunity from being held accountable for illicit activities, drug trafficking, or corruption which "undermines the High Office of Oversight's activities." 25

To illustrate, in 2007, a blanket immunity law pardoned ex-members of Afghan armed factions for international humanitarian law (IHL) and human rights abuses perpetrated before December 2001. Article 3 of the National Reconciliation, General Amnesty and Stability Law grants all belligerent parties and actors involved in fighting from 1972 to 2002 "unconditional immunity from prosecution." This was enacted by two-thirds of the parliament and did not need the signature of former President Karzai, subject to the Afghan Constitution, as underlined by 
Karzai's spokesperson, Wahid Omar. "Parliament is made up largely of former warlords who were accused by Afghans and human rights groups of war crimes" (Leopold, 2010).

60 per cent of parliamentarians are accused of genocide and massacres but they still remain in Afghan parliament. Most have been involved in massacres killing thousands during the seven year war but still serve in parliament as the justice system is weak and the parliament is too strong. In cases of murders, kidnaps and robbery, the police catch them but no one knows what happens next. Once there was a suicide bomber from Pakistan and he came to Kabul and Karzai pardoned him and sent him back to Pakistan with a few hundred lakhs. ${ }^{26}$

Karzai's cabinet consists of leaders of Mujahidin factions and both the vice presidents were responsible for thousands of civilian casualties, but the amnesty law has pardoned them of their retrospective crimes. The UN (2010) and Human Rights Watch (2010) argue that the Amnesty Blanket Immunity Law should be repealed immediately by the Afghan government to prosecute individuals responsible for IHL and human rights violations and avoid releasing these perpetrators from the judicial and correctional processes. The blanket amnesty infringes former President Karzai's 2006 "Action Plan on Peace, Reconciliation and Justice" to combat impunity, accountability for human rights violations, vetting potential political candidates, institutional reform, truth-telling, and documenting past abuses. Yet, Justice Minister Assadullah Ghalib argued that repealing the Amnesty Law would further destabilize the country and government efforts to reconcile with insurgents such as Gulbuddin Hekmatyar who would be accountable for his rocket attacks in Kabul that had killed thousands of innocent civilians during the Mujahidin civil war.

A truly independent Afghan anticorruption agency is lacking which has failed to raise awareness and build the capacity of the civil society. The High Office does not have legislative powers to investigate cases of corruption, and is futile when attempting to investigate elites and con-nected criminals.

\section{Political Imperatives: Drawbacks of Anticorruption Strategy}

When donors try to develop policy initiatives for anticorruption in targeted countries, failure is often the outcome. Donors fail to comprehend 
vast differences between the targeted country that is recovering from conflict - suffering from frailty of a private economy, a weak civil society, political parties' interests, and limited capacity to hold externally driven reforms, such as, a liberalist market democracy. It is useful to have donors with financial capital and ideas for policy initiatives to combat corruption in targeted states, but there are many constraints in a state undergoing conflict or a country just emerging after war, and corruption in each country differs (Cheng \& Zaum, 2008, p. 307). Hence, a one-size-fits-all approach on international anticorruption would be futile. In addition, combating corruption, particularly in a recovering a war-torn state where a peace agreement or interim political arrangement has bought off a few prominent warlords and factions for peace, is not always the best peace-building strategy (Philp, 2008, pp. 310, 324).

Despite the anticorruption rhetoric in Afghanistan, it can be argued that anticorruption only reached the policy level in the ANDS and Paris Conference in 2008, which led to the creation of the HOOAC and the MCTF, but corruption has not been institutionalized or theo-rized. Unrealistic time frames are commonly set by donors. Yet, these initiatives are agreed to by the Afghan government, such as, establishing an efficient and publically trusted police force, incorporating a strong rule of law, and having a more transparent and less corrupt government within five years in the ANDS (2008). International officials argue that Afghanistan is a large and rural country, and thus filling the void with higher numbers of hastily trained police, even if deemed corrupt, is better than nothing, but the problem is not the absence of local police admin-istrations, rather these corrupt institutions "do more harm than good" (Wilder, 2007, p. 57).

The Afghan government has clearly been seized by powerful non-state criminal actors who influence political infiltration during the investigations of corruption and drug-related crime concerning powerful drug traffickers and senior officials affiliated with the drug trade to serve criminal and political interests. In addition, patron-client relations include ruthless and lawless Northern Alliance warlords who lobby with the president due to the international community's short-term bargaining strategy-the Bonn Agreement - for peace and cooperation in the countryside to hunt the Taliban. The blanket amnesty, political interference, and cronyism are the main obstacles to inquiries and investigations concerning graft and grand corruption, which negatively impact anticorruption efforts and lead to the impotence of the HOOAC. 


\section{Failure of Anticorruption Strategy: Narcotics and Religion}

Currently, the counter-narcotics strategy has reduced poppy cultivation but it still generates lucrative income and there are few alternative means of economic necessity to reduce the incentives of Afghans engaging in poppy cultivation. Poppy cultivation is very lucrative for many farmers in provinces across Afghanistan and there are few alternative means of livelihood that provide similar revenue.

Sufficient alternative livelihood programs will not only counter narcot-ics but also reduce incentives for engaging in any illicit activities involved in the opium industry, from cultivation to trafficking, which will help combat drug-related corruption. Alternative livelihood programs at the agricultural level can provide farmers with opportunities to grow licit crops rather than the illicit poppy crop. ${ }^{27}$ This will result in fewer farmers growing poppy, and will thus weaken the narcotics trade that fuels the insurgency and heightens insecurity. Similarly, the International Relief and Development (2008) states that almost one-third of the people in Afghanistan (7.4 million) are susceptible to join the insurgency to feed their families due to low economic security, low household income, and low agricultural productivity.

However, the current anticorruption strategies have failed to com-bat corruption in Afghanistan. The counter-narcotics strategy is failing because the drug trade is far more profitable than the alternative liveli-hoods offered. Alternative livelihood strategy has not prevailed because of poor alternatives to poppy cultivation, which generates 17 times more revenue than wheat. Moreover, the Taliban protect farmers and collect taxes, which has heightened insecurity, particularly in southern Afghanistan.

Despite the futile counter-narcotics efforts, Afghanistan still contrib-utes 92 percent of the global annual opium production-7,333 tons out of 7,922 tons of worldwide opium from 2006 to 2009, which is worth an estimated US\$ 65 billion and kills 100,000 people annually (UNODC, 2009, p. 30). Afghan security forces thereby engage in corrupt activities and drug addiction is a problem in the police and the military. ${ }^{28}$ One in five ANP recruits test positive for drugs, namely, heroin, and are engaged in corruption (Nordland, 2010). Anticorruption strategies are predomi-nantly based on the ideals of powerful Western donors and institutions; the strategies are externally driven, and do not fit in systems of kin-ship and patronage. Western agencies are not connected to the culture, 
conditions, and systems of the Afghan state where kinship and patron-age are prevalent. Religion and ethics could lead to better planning and implementation at the policy level.

Along with law and order and security, religion, colonial heritage, and ethical and dispute traditions are important parts of the social, economic, and political life of the Afghan state. Failure to reform state institutions in postwar states or states undergoing armed conflict, which uphold reli-gious and ethical traditions as a means of everyday society, can actually intensify such movements and support traditional methods of legalism and ethics (Rose-Ackerman, 2008, p. 335).

Adopting religion into anticorruption strategy led to the success of the National Integrity Plan in Malaysia, which increased the pride and integrity within the police force in a society that holds strong religious and spiritual values, and is supported by ethical practice and behav-ior (Embong, 2007, p. 156; Razak, 2006, p. 9). Similarly, Falola (1998, pp. 274-275) contends that the Nigerian government should concentrate on the religions of Islam and Christianity and their ethics to overcome immoralities, such as corruption, greed, and violence, which will lead to meritocracy and fairness when competing for jobs and political office.

Linking religion to anticorruption is very important, particularly in an Islamic state. In Afghanistan, the Mujahidin radicalized religion to fight against the Soviet invasion. In addition, the Taliban is radicalized by Mullah Omar to fight Western intervention and destroy America. Mullah Omar opened up Afghanistan for Bin Laden and other rich and powerful Islamic activists, and they advanced radicalism which resulted in international segregation and a strict Islamic regime. Mullah Omar taught in a "madrasa" and radicalized refugees in Pakistan camps by inspiring his students to arm themselves to capture and kill the abusive and unjust warlords who terrorized, raped, and murdered local Afghans to fulfill Allah's work. The Shaldara madrasa located in the Pashtunabad district, Quetta, Pakistan, has allegedly recruited and radicalized vulnerable young men who join "the Taliban as suicide bombers in Afghanistan" (Gohel, 2009, p. 137).

Although the Taliban and Al-Qaeda did not initially share the same ideology, the Taliban became radicalized under jihadist ideas to ward off Western intervention after the US coalition military campaign during October and November 2001. After the US invasion, the Afghan Taliban fled the country and entered Pakistan to radicalize the Pakistani Taliban. Mullah Omar and the Taliban shared Bin Laden's ideological 
position, which previously led to the destruction of Bamiyan's Buddhas, arrests of Christian humanitarian aid workers, and Omar's declaraton on November 15, 2001, to the British Broadcasting Corporation to destroy the US.

A Mullah is required to rise and intertwine religion in the Islamic State of Afghanistan in order to promote an ideology and national pride to curb corruption because "Mullah Omar radicalized the Taliban via religion and this insurgency fights constantly with little remuneration. However, try telling this to the international community. They will never put religion at the basis of anti-corruption strategy." ${ }^{29}$ During the 1990s, the lower Mujahidin police "were not engaged in corruption because they worked for a mandate; to protect people and have national pride for Afghanistan" but this has now been lost. ${ }^{30}$ The IWA's Afghan public corruption survey (2010, p. 95) also underlines that Mullah and Ulema (55 percent of survey respondents) are the best institutions to efficiently combat corruption, with only 25 percent claiming that they would not be efficient to do so. Mullahs, Ulema, and other trusted local power-holders can be trained and empowered to raise awareness about anticorruption, counter-narcotics, and human rights. In addition, this can build accountability from the bottom-up approach. In Helmand, com-munity councils can contain 300 elders discussing legal rights and other issues and the Human Rights Commission trains the Shura members to consolidate discussions "to their Mullahs." 31

Anticorruption strategies in Afghanistan are merely based on secular Western ideals and implemented in short-term programs via bilateral and multi-donor projects with different goals. Without a system or institutionalization, the mind-sets are not changed for corrupt think-ing; therefore, even if the police are paid more, say even $£ 40,000$ or much higher, they will still do corrupt things. ${ }^{32}$ More Western aid and external short-term policies driven by the international community for statebuilding will increase corruption by forming more revenue and opportunity.

The major problem of corruption in Afghanistan is that it is multi-faceted: administrative and systemic corruption, aid corruption, patron-age, and state capture. This has been recognized, that is, it has been mentioned in the ANDS (2008), but it is the political imperatives of anticorruption strategies, often externally driven by powerful Western donors, agencies, and institutions, that contribute to the failure of curbing corruption in Afghanistan. 


\section{Conclusion}

Much of the international aid spent on Afghanistan is for reforming the security forces and most of it is wasted by graft. Corruption and clientelism are difficult to challenge as both are systemically rooted in the Afghan government and make it hard for poor families to afford public services that expect bribes, which is accepted as a norm for getting things done. Former President Karzai has granted amnesty and nominated warlords who were notable human rights violators during the 1990s into his cabinet, protects his political cronies from prosecution, and transfers rather than dismisses ministers and governors involved in drug-related corruption. In addition, notorious drug mules affiliated with the government are released immediately when arrested by the police. ${ }^{33}$ Pyman, Cohen, Boardman, Webster and Seymour (2012, p. 33) also recognize that Afghan police officers continue to release detainees who have been arrested for drug charges in exchange of bribes, and some bribes for Taliban detainees can reach US\$10,000.

Bribery is usually affiliated with low pay, which is why PRR and P\&G scaling has been installed to remove survival-based corruption because many civil servants at the subnational level are living in poverty and struggling to cater for their families. Azfar and Nelson Jr (2007, p. 471) state that, "Increasing government wages and increasing the difficulty of hiding corrupt gains both reduce corruption." Afghan anticorruption strategy features $P \& G$ to raise the salaries of lowly paid public sector employees to avoid survival-based corrupt practices of bribery and extor-tion. Corruption is mainly associated with bribery, weak law enforcement, and drug trafficking. Administrative corruption, aid corruption, state capture, and patronage are the multiple causes of corruption that interact and are interpenetrating.

Despite the anticorruption efforts, low capacity of the HOOAC and efforts of the MCTF and other anticorruption units have failed to challenge impunity within the Afghan government. No minister or pro-vincial governor has been indicted for acts of corruption. State capture and political corruption seriously hinder the effectiveness of the rule of law, justice, meritocracy, and anticorruption efforts, strategies, and units because the government and political elites are manipulated into drug-related corruption by the infiltration of non-state criminal interests.

Other anticorruption strategies include alternative livelihood programs to combat poppy cultivation, which can assist anticorruption efforts. 
However, alternative livelihoods have failed to provide incentives for farmers to surrender lucrative poppy cultivation and the anticorruption strategy is driven by donors who assist in drafting unrealistic goals. In addition, the role of religion and ethics as a strategy to combat corruption is not taken seriously in Afghanistan, which is a state based on kinship and patronage that makes curbing corruption a challenge for the Western agencies.

All these problems with anticorruption are due to the political imperatives of the international community that supported Tajik Northern Alliance warlords during the Bonn Agreement to fight the Taliban. As a result, donors and NGOs have focused on security objectives and have funded CSOs. Most importantly, the HOOAC is still hindered by Afghan political interference and remains attached to the Presidential Office. Therefore, systemic corruption and clientelism in a weak and narco-state with fragile institutions and a legacy of warlordism - the patrons who distribute state resources to clients in exchange for loyalty-is extremely difficult to combat, particularly in Afghanistan. This is due to these deep roots of corrupt patron-client relations that were reinforced by the international community and former President Karzai, resulting in state capture, cronyism, and the amnesty law that should be repealed. An alternative approach such as adopting religion and enhancing the role of powerful local leaders, such as, Mullahs and Ulema, could have an impact on combating corruption and human rights abuses by elders discussing such issues at community councils and building accountability from the bottom-up process as well. These trusted figures in the countryside can wage a jihadist war against corruption, which deteriorates the morals and ethics of an Islamic state. This would be similar to how Mullah Omar radicalized the Taliban against Western intervention.

Besides pay reform that can increase the salaries of the Afghan security forces and judges, with further reform, to reduce corruption due to the lack of economic necessity, other factors are required to strive toward a comprehensive anticorruption strategy. This is to fight systemic corrup-tion, clientelism, and state capture, including the government, security, and judicial institutions that serve and protect lucrative drug interests of illegal criminal networks, armed groups, and corrupt elites. The strategy is based on the six points raised in international and successful domestic anticorruption strategies, namely, (i) raising awareness, (ii) prevention, (iii) prosecution and sanctions, (iv) detection, (v) a collaborate counter-narcotics strategy to challenge state capture, and (vi) and linking religion 
with anticorruption. A holistic anticorruption strategy for Afghanistan, which reflects on the literature and interviewee responses on how to benefit the reform of both security and justice sectors includes the following recommendations to reduce corruption and clientelism over time:

\section{Raising awareness}

i. Publication of documents on anticorruption, reporting procedures, and rights

ii. Anonymous whistle-blowing when making complaints against public officials

iii. Legal training and education on legal practice, human rights, and corruption

iv. Promoting a culture of zero tolerance-no immunity for crimes of corruption and repeal the amnesty law

v. Transparency in public procurement to ensure that all funds are not misused

vi. Revised Police Code of Conduct (for consistency) and more familiar community police

vii. Strong communication between all the various stakeholders, institutions, and agencies involved in all reforms and anticorruption strategies to avoid wasted capital

viii. High media coverage, naming, and shaming-for education/ moral deliberation

\section{Prevention}

i. Raise the salaries of the civil service, security, and justice actors to prevent individual and organization deviancy and compete with the private sector to enhance incentives for educated, honest, and trustworthy applicants

ii. Promote private competition so that markets can compete for economic growth

iii. Promote PAR to reduce overlapping of functions and oversight from IARCSC of civil servants and ministerial equivalents

iv. Follow constitutional procedures as there are anticorruption and antidrug laws that are often not pursued-resist political interference and abide by laws 
v. Boost the capacity of CSOs as pressure points to voice/campaign against corruption and promote human rights, such as gender justice at the Jirga and Shura levels

vi. Understand nepotism and conflicting interests as an initial anticorruption policy

vii. Quarterly auditing and monitoring, including funds from external bodies, per diems, and salaries to police the misuse of funds and financial remuneration benefits

viii. Build the capacity of the government and the justice and security institutions

ix. Stronger vetting procedures to ensure that all appointments of public officials and security and judicial personnel are meritocratic and not based on clientelism or other corrupt means, including governors and police chiefs bidding for posts at poppy-rich provincial levels

\section{Prosecution and punishment/sanctions}

i. Empower the HOOAC, Anti-Corruption Unit (ACU) and the AGO's specialized units to investigate corruption cases independently that are free from political interference and thirdparty infiltration

ii. Enforce accountability_independent judiciary to apply harsher disciplinary procedures, fines, and custodial sentences for corruption and drug offences

iii. Transfer HOOAC, ACU, and AGO-investigated cases to the Ministry of Justice (MoJ) and the Supreme Court to try and prosecute crimes of corruption

\section{Detection}

i. Maintain MoI and MoJ control with internal investigation units

ii. Build the capacity of the HOOAC and IARCSC legal author-ity complaints procedure to boost the quality of the services dealing with corruption claims

iii. Build the capacity of the CAO to monitor fiscal spending and control funds to detect embezzlement of funds in public office

iv. Ensure that all international monies and activity are tracked by the Afghan Ministry of Finance so that transparency is endorsed at both ends, not only international actors 
monitoring Afghan fiscal activity but also spending from international agencies being traced.

v. Empower the HOOAC as the highest level of oversight with independence to truly implement UNCAC and laws contained in the Afghan Constitution to curb corruption

\section{Collaborative counter-narcotics system (CCNS)}

i. Ensure that all Afghan ministries have a functional and internal collaborative counter-narcotics system (CCNS) and communicate with each other to enforce existing antidrug laws and follow the procedure under the Afghan Constitution

ii. Promote the understanding of state capture by political elites related to drug smuggling and lucrative illicit deals leading to criminal activity and corruption

iii. Increase the political will of international donors to work with the new government on enforcing anticorruption strategy as a main priority of the ANDS and future conferences and reduce political intrusion in such efforts

iv. Install more legal authority for the AGO, ACU, HOOAC, and the MCTF to investigate all forms of corruption, especially drug trafficking that is prevalent at the southern (trading) provincial level

v. Support measures/regulations that protect these specialized anticorruption units from political interference in major cases, even if political aides

vi. Install the NDCS to fight illicit poppy cultivation

vii. Continue the promotion of alternative livelihood programs, such as the Afghanistan Vouchers for Increased Production in Agriculture Plus; Afghanistan Water, Agriculture and Technology Transfer; and Roots of Peace. This is to help farmers cultivate substitute crops to weaken poppy incentives that fund the insurgency which causes nationwide insecurity

\section{Linking religion to anticorruption strategy}

i. Training on morality and ethics to empower the role of Mullahs and Ulema that links the detriments of corruption and human rights abuses with Islam

ii. Enhance capacity of the local organizations and CSOs to train and/or include trusted local figures - such as Mullahs and Ulema-in anticorruption and basic rights dialogue 
iii. Anticorruption and basic rights dialogue can commence in community councils - at the Jirga and Shura level—to have a greater impact and higher inclusion rates in the countryside

iv. Empower trusted local figures and the civil society at the community level in order to enhance accountability from the bottom-up levels also

v. Link cultural values, ethics, morality, and religion with anticorruption and basic rights dialogue to wage a religious effort to curb corruption

In sum, the Afghan state is fuelled with corruption that has also hindered security and justice. It is imperative that the new Afghan president take anticorruption very seriously to boost legitimacy and development of the state and deter the insurgency and drug trafficking. The lessons that can be learned from this case are largely based on the bureaucratic reform efforts to combat corruption that has reduced the overlapping of duties and increased the wages of the civil services and public officials. However, bargaining with warlords in exchange for short-term peace by including human rights abusers in cabinet positions intensifies drug-related corruption and further, the patron- client relations have destabilized security and the rule of law. Prevalent corruption and weak overly centralized legal systems in the countryside have resulted in Taliban resurgence to fill the void. The Taliban has utilized religion and morality to fight the Afghan government and the West. Other countries can learn that in non-secular societies, formal anticorruption strategy can help but it is religion and the empowerment of trusted local power-holders such as religious figures - rather than warlords to merely fight an insurgency - that can help to wage a religious war to oust corruption.

\section{ACKNOWLEDGMENTS}

The author would like to thank Dr David Connolly—of the PRDU at the time of this research - for establishing the initial gatekeepers in the field. The field visit in Kabul during May-June 2010 was mainly conducted within the areas of Wazir Akbar Khan, Shar-e-Naw, and Flower Street due to the location of the Park Palace guesthouse. The researcher would wish to provide special thanks to all of the respondents involved and hospitality of the Afghan public. 


\section{NOTES}

1. Author interviews with the Advisor of the Afghan Civil society Forum (ACSFo), Kabul, June 1, 2010, 10:45; Program Director for Law, Human Rights and Women's Empowerment of The Asia Foundation, Afghanistan, Kabul, May 26, 2010, 16:00; Project Coordinator of the Centre for Policy and Human Development (CPHD), Kabul, May 27, 2010, 12:00; Justice Sector Support Program Legal Consultant to the AGO, Kabul, May 29, 2010, 15:00.

2. Author interviews with the Deputy Chair of the Afghanistan Independent Human Rights Commission (AIHRC), Kabul, May 27, 2010, 09:00; Deputy Executive Director of the Ministry of Rural Rehabilitation and Development (MRRD): Afghanistan Rural Enterprise Development Program (AREDP), Kabul, June 1, 2010, 12:00; Peacebuilding and Public Relations Manager of ACSFo, Kabul, June 1, 2010, 11:00; Advisor of the HOOAC, Kabul, June 4, 2010, 14:00.

3. Author interviews with the Director of the American Institute of American Studies, Kabul, May 26, 2010, 15:00; Head of Access to Justice Program for The Asia Foundation, Kabul, May 26, 2010, 16:00; Senior Rule of Law Advisor of the United States Institute of Peace (USIP), Kabul, May 30, 2010, 14:00.

4. Author interview with the Resident Director for Elections of National Democratic Institute for International Affairs, Kabul, June 3, 2010, 15:30.

5. The Compact was authorized by UN Security Council Resolution 1659 (2006).

6. Author interview with the Country Director of Flag International Afghanistan, Kabul, May 26, 2010, 11:00.

7. This Commission was established on May 23, 2002 via Presidential Decree No. 257 which was then regulated to Decree No. 26 on June 10, 2003 which extended the duties of the Commission into an IARCSC.

8. Author interview with the Executive Director of International Assistance Mission (IAM), Kabul, Monday May 31, 2010, 14:00.

9. Author interview with the Executive Director of IAM, Kabul, May 31, 2010, 14:00.

10. As on January 23, 2015, AFN 57.3792 amounts to USD \$1.

11. Author interview with the Operations Officer for the World Bank's Afghanistan Reconstruction Trust Fund (ARTF), Kabul, June 5, 2010, 11:00.

12. Author interview with the Advisor of the HOOAC, Kabul, June 4, 2010, 14:00.

13. Author interview with the Advisor of the HOOAC, Kabul, June 4, 2010, 14:00. 
14. Author interview with the Country Director of Global Rights-Partners for Justice, Kabul, June 3, 2010, 17:30.

15. Author interviews with the Senior Rule of Law Advisor for USIP, Kabul, May 30, 2010, 14:00; Attaché-Justice, Rule of Law and Human Rights of the European Union (EU) Delegation to Afghanistan and Office of the EU Special Representative, Kabul, June 6, 2010, 17:45.

16. Most CAO cases submitted to the AGO are returned with no action taken (SIGAR, 2011, p. 77).

17. Author interview with the Advisor of the HOOAC, Kabul, June 4, 2010, 14:00.

18. Author interview with an employee of the NDS, York, December 2, 2011, 16:00.

19. Author interview with the Advisor for the HOOAC, Kabul, June 4, 2010, 14:00.

20. Research assistant (with author present) focus group with students of the Faculty of Law and Political Science, Kabul University, Kabul, June 6, 2010, 09:00.

21. Author interview with the Team Leader of USAID's Afghanistan Rule of Law Project (ARoLP), Kabul, June 3, 2010, 16:15.

22. Author interview with the Team Leader of ARoLP, Kabul, June 3, 2010, 16:15.

23. Author interview with the ARTF's Operations Officer, Kabul, June 5, 2010, 11:00.

24. Author interview with the Advisor of the HOOAC, Kabul, June 4, 2010, 14:00.

25. Author interview with the Advisor of the HOOAC, Kabul, June 4, 2010, 14:00.

26. Author interview with the Peacebuilding and Public Relations of ACSFo, Kabul, June 1, 2010, 13:00.

27. Supplying and educating farmers to grow grapes, almonds and pistachios are alternative means of livelihoods (author interviews with the Country Director of Flag International Afghanistan, Kabul, May 26, 2010, 11:00; Country Director of Roots of Peace, Kabul, May 30, 2010, 18:45).

28. Author interview with the Country Director of Flag International Afghanistan, Kabul, May 26, 2010, 11:00.

29. Author lunch conversation with the Chairman of the Post-war Reconstruction and Development Unit (PRDU), York, February 3, 2012, 14:30.

30. Ibid.

31. Author interview with the Department for International Development Justice Advisor: UK Aid, Kabul, June 6, 2010, 13:00. 
32. Author lunch conversation with the Chairman of the PRDU, York, February 3, 2012, 14:30.

33. Author interviews with the Deputy Chair of the AIHRC, Kabul, May 27, 2010, 09:00; Deputy Executive Director of MRRD: AREDP, Kabul, June 1, 2010, 12:00; Peacebuilding and Public Relations Manager of ACSFo, Kabul, June 1, 2010, 13:00; Advisor of the HOOAC, Kabul, June 4, 2010, 14:00.

\section{REFERENCES}

Afghanistan Compact. (2006). Building on success: The London conference on Afghanistan. London, 31 January-1 February 2006.

Afghanistan National Development Strategy. (2006). An interim strategy for security, governance, economic growth and poverty reduction, volume I. Kabul: Islamic Republic of Afghanistan.

Afghanistan National Development Strategy. (2008). Afghanistan National Development strategy 1387-1391 (2008-2013): A strategy for security, governance, economic growth and poverty reduction. Kabul: Islamic Republic of Afghanistan.

Arnoldy, B. (2010). The man leading Afghanistan's anti-corruption fight. The Christian Science Monitor. Retrieved October 17, 2010, from http://www. sabawoon.com/articles/index.php?page=courtForMinisters

Asian Development Bank. (2005). Report and recommendation of the President to the Board of Directors: Proposed programme cluster of loans to the Islamic Republic of Afghanistan for the fiscal management and public administration reform program. Manila: ADB.

Azami, S. (2009). The need for security sector reform in Afghanistan to curb corruption. Peace \& Conflict Monitor, 4 November. Retrieved December 16, 2010, from http://www.monitor.upeace.org/innerpg.cfm?id_article $=666$

Azfar, O., \& Nelson, W.R., Jr (2007). Transparency, wages, and the separation of powers: An experimental analysis of corruption. Public Choice, 130(3/4), 471493.

Cheng, C.S., \& Zaum, D. (2008). Introduction - key themes in peacebuilding and corruption. International Peacekeeping, 15(3), 301-309.

Embong, A.R. (2007). Islam and democracy in Malaysia. In Z. Hasan (Ed.), Democracy in Muslim societies: The Asian experience (pp. 128-176). New Delhi: SAGE publications.

Falola, T. (1998). Violence in Nigeria: The crisis of religious politics and secular ideologies. Rochester, NY: University of Rochester Press.

Farmer, B. (2009, September 6). Afghanistan: Senior female judge accuses Hamid Karzai over release of drug lords. The Telegraph. Retrieved August 3, 2011, 
from http://www.telegraph.co.uk/news/worldnews/asia/afghanistan/6147248/ Afghanistan-senior-female-judge-accuses-Hamid-Karzai-over-release-of-druglords.html

Giustozzi, A., \& Isaqzadeh, M. (2013). Policing Afghanistan: The politics of the Lame Leviathan. London: Hurst \& Company.

Gohel, S.M. (2009). The Afghanistan-Pakistan border areas: Challenges, threats and scenarios. In House of Commons-Foreign Affairs Committee (Ed.),

Global security: Afghanistan and Pakistan: Eighth report of session 2008-09 (pp. 131-141). London: The Stationery Office.

Hafvenstein, J. (2011). Afghanistan's opium strategy alternatives-A moment for masterful inactivity? In W. Mason (Ed.), The rule of law in Afghanistan: Missing in inaction (pp. 123-146). Cambridge: Cambridge University Press.

Human Rights Watch. (2010). Afghanistan: Repeal amnesty law. Human Rights Watch, 10 March. Retrieved October 8, 2010, from http://www.hrw.org/en/ news/2010/03/10/afghanistan-repeal-amnesty-law

Independent Administrative Reform and Civil Service Commission. (2005).

Review: Priority reform and restructuring initiatives. Kabul: IARCSC. Integrity

Watch Afghanistan. (2010). Afghan perceptions and experiences of corruption: A national survey. Kabul: Integrity Watch Afghanistan. International

Relief and Development. (2008). Agricultural vouchers in Afghanistan: Giving farmers more opportunities. International Relief and Development. Retrieved February 12, 2011, from http://www.ird-dc.org/what/ programs/avipa.html

Jackson, A. (2010, July 19). Promises, promises: A briefing paper for the Kabul conference on Afghanistan. Kabul: Oxfam International.

Kabul International Conference on Afghanistan. (2010, July 20). Afghanistan National Development Strategy — prioritization and implementation plan: Mid 2010-Mid 2013 volume I. Kabul: Ministry of Finance, Department of Policy.

Leonard, B. (2008, June). United States plan for sustaining the Afghanistan National Security Forces. Report to Congress in accordance with the 2008 National Defence Authorization Act (Section 1231, Public Law 110-181).

Leopold, J. (2010, March 16). Afghanistan enacts law that gives war criminals blanket immunity. New York: International Centre for Transitional Justice.

Lister, S. (2007). Understanding state-building and local government in Afghanistan, crisis states working papers series no. 2. Working Paper No. 14.

Nordland, R. (2010, February 2) With raw recruits, Afghan buildup falters. The New York Times. Retrieved February 19, 2011, from http://www.nytimes. com/2010/02/03/world/asia/03afghan.html 
Paris Conference. (2008, June 12). Declaration of the international conference in support of Afghanistan: President of the French Republic, President of the Islamic Republic of Afghanistan and The Secretary-General of the United Nations. Paris: Paris Conference.

Philp, M. (2008). Peacebuilding and corruption. International Peacekeeping, 15(3), 310-327.

Pyman, M., Cohen, J., Boardman, M., Webster, B., \& Seymour, N. (2012). Arresting corruption in the police: The global experience of police corruption reform efforts. London: Transparency International UK.

Razak, N.T. (2006). Globalizing Malaysia: Towards building a developed Nation. Selangor, Malaysia: MPH Group Publishing.

Rose-Ackerman, S. (2008). Corruption and government. International Peacekeeping, 15(3), 328-343.

Saghafi-Ameri, N. (2010). The "Afghan drugs" problem - a challenge to Iran and international security. Iranian Review of Foreign Affairs, 1(2), 213-235.

Singh, D. (2014). Corruption and clientelism in the lower levels of the Afghan police. Conflict, Security \& Development, 14(5), 621-650.

Special Inspector General for Afghanistan Reconstruction. (2009). Afghanistan's High Office of Oversight needs significantly strengthened authority, independence, and donor support to become an effective anti-corruption institution. SIGAR Audit 10-2, 16 December.

Special Inspector General for Afghanistan Reconstruction. (2011). Press release: SIGAR audit reveals risks to U.S. aid dollars, development of sound Afghan financial sector. SIGAR, 20 July. Retrieved February 11, 2012, from http:// www.sigar.mil/PressRelease20JULY2011.asp

Suhrke, A. (2007). Reconstruction as modernization: The 'post-conflict' project in Afghanistan. Third World Quarterly, 28(7), 1291-1308.

The Asia Foundation. (2009, September 9). The Afghanistan High Office of Oversight for Anti-Corruption - a glimmer of hope. Retrieved August 2, 2011, from http://asiafoundation.org/in-asia/2009/09/09/the-afghanistan-high-office-ofoversight-for-anti-corruption-\%E2\%80\%93-a-glimmer-of-hope/

United Nations. (2010, March 25). Top UN human rights official in Afghanistan calls for repeal of amnesty law. UN News Centre. Retrieved August 4, 2011, from http://www.un.org/apps/news/story.asp?NewsID=34198

United Nations Office on Drugs and Crime. (2009). Addiction, crime and insurgency: The transnational threat of Afghan opium. New York: UNODC.

United Nations Office on Drugs and Crime. (2012, December). Corruption in Afghanistan: Recent patterns and trends—summary findings. Vienna: UNODC. 
Wilder, A. (2007). Cops or robbers? The struggle to reform the Afghan National Police. Kabul: Afghanistan Research and Evaluation Unit.

Danny Singh has worked as a teaching fellow for the Post-war Reconstruction and Development Unit at the University of York. He is currently conducting some research at Leeds Beckett University on the criminological approaches of corruption in Afghanistan while undertaking a part-time role at the University of York's Library. His primary research interests are corruption, clientelism, security sector reform and human rights in the war-torn state, namely, Afghanistan, where he has conducted field research. He has recently published about police and judicial reform in Conflict, Security \& Development and Journal of Intervention and Statebuilding, respectively. [email: danny.singh@york.ac.uk] 